\title{
INTERVALLING EFFECT ON ESTIMATING THE BETA PARAMETER FOR THE LARGEST COMPANIES ON THE WSE
}

\author{
Prof. Wiesław Dębski \\ University of Finance and Management in Warsaw \\ Pawia 55, 01-030 Warszawa, Poland \\ wdebski@vizja.pl \\ Ewa Feder-Sempach, Ph.D. \\ University of Lodz \\ Faculty of Economics and Sociology \\ POW 3/5, 90-255 Lódź, Poland \\ ewafeder@wp.pl \\ Bartosz Świderski, Ph.D. \\ Warsaw University of Life Sciences \\ Nowoursynowska 166, 02-787 Warszawa, Poland \\ jbswiderski@wp.pl
}

Received 23 May 2014, Accepted 9 February 2015

\begin{abstract}
In the modern portfolio theory investment risk plays a crucial role. It is the subject of numerous studies and publications, in particular in relation to the management of investment portfolios. Commonly used measure of investment management in equities is a beta parameter, which is used to estimate individual stock risk and portfolio risk. In particular, numerous studies the subject of which are the beta parameter properties such as stability in the context of the stock market cycle phases, intervalling effect, length estimation sample etc. The main objective of this paper is to investigate the intervalling effect on the beta parameter. The empirical analysis is carried out for the 33 largest companies of the Warsaw Stock Exchange (WSE) on a sample from the years 2005 to 2012 on the basis of daily, weekly and monthly rates of return. Statistical verification of the hypothesis of the importance of the frequency measuring the return of shares will be based on the singleindex Sharpe's model.
\end{abstract}

Keywords: beta parameter, intervalling effect, largest companies on Warsaw Stock Exchange.

JEL classification: G11, G01. 


\section{Introduction}

In modern finance, especially in the portfolio theory, the investment risk plays a crucial role. It is a subject of many studies and publications, especially in the context of investment portfolios management. The common measure used for managing investments in shares is the beta parameter, which is used to estimate the market risk (systematic risk) of shares or a portfolio consisting of shares. The beta parameter was introduced to the literature of finance in the early 1960s and since that time it has been subject to numerous studies and empirical analyses. Such research was especially intensively conducted in highly developed economies in the 1970s and 1980s. Afterwards, numerous studies, mainly the empirical ones, concerning the beta parameter as the measure of systematic risk were conducted in the countries defined as emerging markets. In the world literature the subject of research referring to the beta parameter is very extensive, however a special attention should be drawn to the research on the context of the relation of the rate of return from shares or portfolios of shares and the rate of return from the market portfolio and the research on its properties from the viewpoint of the distinction of phases of the stock exchange cycle, the frequency of measurement of the rate of return (intervalling effect), the length of the estimating sample or the purely statistical properties resulting from e.g. the application of a certain estimating method or the occurrence of autocorrelation phenomenon. The analysis also embraces such properties as stability, stationarity, and the predicting power of the beta parameter.

In Poland there is a particular need to conduct research referring to the beta parameter, since the shares market started to grow only after the system transformation in 1989. Considering the second decade of the 21 st century it can be claimed to be tolerably well developed and allowing to collect properly extended research samples. The research conducted so far have been first of all of fragmentary nature and there is a need to carry out more complex research.

The main purpose of this paper is to analyze the influence of the measurement frequency rate of return from shares on an estimated value of the beta parameter. An empirical analysis will be conducted for 33 largest companies from Warsaw Stock Exchange on the sample from the period 2005-2012 ${ }^{1}$ on the basis of daily, weekly and monthly rates of return (intervalling effect). It must be admitted that the above sample embracing both the upturns and downturns of the economy in the stock market, is well-suited to the above analysis. The verification of the quoted hypothesis about the significance of the influence of frequency measuring rate of return of the largest stock exchange companies in Poland will be run on the basis of a single-index Sharpe's model. What will be verified is the hypothesis about the equality of beta parameters 
estimated on the basis of the weekly and daily data as well as the monthly and weekly data. Its empirical verification will appear on the basis of a t-Student test ${ }^{2}$. The paper has been divided into two main parts, where the first one presents a brief review of the literature of the subject and some basic outcome of empirical research as well as the methodology of the conducted analysis, however in the second part there is a presentation of the results, obtained by the authors in the course their own research, together with the conclusions.

\section{Review of the basic literature and empirical research}

The beta parameter was introduced to the modern portfolio theory by Sharpe $\mathrm{e}^{3}$ in as a slope of a single-index model relating the rate of return from a single share to the rate of return of the market (stock exchange index). That publication triggered the studies and research on beta parameter as a measure of systematic risk of investments in shares. Especially intensive studies were conducted in highly-developed economies including the USA. The research concerned various aspects of the beta parameter. Firstly they started to test its certain properties, e.g. stability, mainly in the context of the stock exchange cycle phases (bull and bear markets) and also the prognostic power. Here we can quote the publication by M. Blume ${ }^{4}$, which was one of the first and most advanced studies in this field. When examining the prognostic power of the beta parameter he claimed that the estimates of this parameter obtained on the basis of historical data for single shares and smaller portfolios hardly increase the accuracy of forecasting. That accuracy was significantly better in the case of large portfolios. The research was conducted on the basis of monthly rates of return for the constructed seven-year research periods from 1926-1968. A conclusion similar to that of Blume's was drawn by R. Levy ${ }^{5}$ in his research.

In the papers published later on, the prognostic power of beta parameters is examined in the context of the phases of the stock exchange market, assuming that if they are estimated separately in the bull and bear market, then the prognosis of the systematic risk of the shares will be more accurate. An essential paper in this field was an article by R. Levy ${ }^{6}$ from 1974. However, other authors, e.g. F. Fabozzi and J. Francis ${ }^{7}$ claimed on the basis of their own research that there was no need to calculate beta parameters separately for the bull and bear markets, since the estimated beta parameters for the absolute majority of companies' shares are constant for the both conditions of the stock exchange market (Fabozzi and Francis examined 700 NYSE companies on the basis of monthly rates of return from January 1966 to December 1971). The outcome obtained by M.Kim and K. Zumwalt ${ }^{8}$ is contradictory to the previous findings, since they claimed that beta parameters estimated separately for the upturn and downturn markets have 
stronger prognostic power in estimating the risk for the future investments. The following works in this field either confirmed the conclusions from Levy's research of 1974 or they contradicted it. For example, we can mention here the following papers: Eubank and Zumwalt ${ }^{9}$, $\mathrm{Chen}^{10}$, Alexander and Benson ${ }^{11}$, Fisher and Kamin ${ }^{12}$, Brennan and Copeland ${ }^{13}$, Lin, Chen ${ }^{14}$, Clarkson, Thompson ${ }^{15}$, Sercu and others ${ }^{16}$. In these publications the beta parameter was also considered in the context of other questions, e.g. the length of the estimating sample, size of the portfolio, size of the company, the flow of the shares turnover, intervalling effect etc.

As the research indicates, the intervalling effect of shares undoubtedly has some influence on the value of the estimated beta parameter, and therefore on the size of the systematic risk from a share. An essential aspect here is an examination of the beta parameter sensitivity to the change of this measurement frequency that is showing how the rate of return measurement moves from daily to weekly or from weekly to monthly and how these changes influence the value of the estimated beta parameter. This question was subject to numerous empirical analyses. For example G. Hawawini ${ }^{17}$ on the basis of the research for 20 companies from NYSE from the period of January 1970 to December 1973, indicated that the beta values of shares were changing noticeably depending on whether the estimation was based on the daily, weekly or monthly rate of return. The same conclusion was drawn by P. Handa and others ${ }^{18}$, However, P. Daves ${ }^{19}$ and others suggested that in order to estimate the beta parameter of shares one should apply a daily rate of return, since due to that the accuracy of beta estimation is increasing. A. Damodaran ${ }^{20}$ also found remarkable differences in the estimated values of the beta parameter from shares depending on the applied frequency of the rate of return measurement. He also pointed at the estimated beta value being dependent on the kind of the stock exchange index used as a proxy of the market index in Sharpe's model. Apart from the above mentioned researchers, there were also others who dealt with the problem of the influence of the frequency of measurement of the rate of return from a share or a portfolio of shares on the beta parameter. The most significant papers in this field are the following: Saniga ${ }^{21}$ and others, Corhay ${ }^{22}$, Mukherji ${ }^{23}$, Kriszna ${ }^{24}$, Armitage, Brzeszczynski ${ }^{25}$.

The research of the influence of intervalling effect on the beta parameter were conducted also in Poland. Extensive research in this field was done by E. Feder-Sempach ${ }^{26}$ who carried out a detailed analysis of the investment risk in the Polish stock market and estimated beta parameters for the largest companies listed on the Warsaw Stock Exchange (WSE) for different intervals of the rate of return measurement in the period 2000-2008. Another important study is research by Brzeszczynski ${ }^{27}$ and others, who carried out an empirical analysis of the intervalling effect for shares of the WSE companies on the estimated beta parameters. The research indicated 
essential differences in the estimates of the beta parameter for the same companies due to an interval of the rate of return measurement.

\section{Relationship between the rate of return measurement interval and the beta parameter}

Due to numerous research on the intervalling effect on beta parameter, one can notice several relationships. In most of the studies the beta parameter is estimated according to the weekly or even monthly intervals. Generally, a monthly interval is used by financial institutions such as Merrill Lynch, Value Line, S\&P. In spite of being more frequently used, the beta parameter estimated on the basis of monthly data has similar drawbacks to those estimated on daily or weekly data. The choice of the rate of return measurement frequency is crucial in assessing the risk and it entails subsequent relations, extensively covered in the literature of the subject.

One of the first such relations that have ever been observed related the estimated beta parameters within different rate of return measurement intervals with the degree of fit of empirical rates of return to the line of regression, expressed by determination coefficient $R^{2}$. The phenomenon was described by K. Smith ${ }^{28}$ who claimed that the extension of the rate of return measurement interval entailed the increase of the coefficient $R^{2}$. The author did not, however, give the final answer as to which was the right interval in determining beta parameters, but he claimed that it should be adjusted to the horizon of the investment.

Another confirmation of the positive relation between the determination coefficient $R^{2}$ and the extension of rate of return measurement interval in estimating the beta parameter is a study by several authors - K. Cohen, G. Hawawini, S. Maier, R. Schwartz i D. Witcomb ${ }^{29}$. The authors analyzed a few phenomena observed in the capital market and they noticed an increase of the level of determination coefficient depending on the extension of the rate of return measurement interval. Additionally they noticed that beta parameters of shares with small volume of turnover were rising along the extension of the measurement interval, while beta parameters of shares with big volume of turnover were decreasing.

Another explanation of the phenomenon of the intervalling effect on the beta parameter can be found in the paper by B. Bjornson ${ }^{30}$ and others. Its authors claimed that beta as a measure of systematic risk that is mainly caused by macroeconomic factors, was changing together with the change of the measurement interval, since the frequency of changes of macroeconomic factors was varying. In the study an attempt was made to explain a higher risk characterizing 
shares of small companies. They found out that the shares of small companies with low capitalization were more sensitive to the risk factors which occurred with low frequency, with investors expecting a higher premium for the risk.

Another attempt to explain the influence of the rate of return measurement interval on risk was made by P. Handa ${ }^{31}$ and others. They stated that sensitivity of beta to the change of a measurement interval was caused by the fact that the covariance between the rate of return from a share and the market was changing differently (disproportionately) from the variation of the market portfolio. Beta parameters of risky shares are increasing together with the rise of the interval and those of safe shares are falling.

An alternative explanation was suggested by R. Daves ${ }^{32}$ and others. On the basis of data from the American market they claimed that a standard deviation in estimating beta parameter was increasing together with the extension of an interval.

Numerous empirical data indicate and clearly show that there is an influence of the change of the rate of return measurement interval on risk estimation measured with the beta parameter. For this reason the traditional method of beta estimating and the arbitrary choice of an interval leads to remarkable simplification. A lot of information about the changes of beta together with the change of an interval is lost and the very analysis on the risk occurrence becomes onedimensional and inadequate in the case of contemporary investments.

\section{Methodology of the research}

The research involved selected shares of the largest WSE companies belonging to indexes of WIG20 (14 companies) and mWIG40 (19 companies) in the period 2005-2012. The rates of return were calculated on the basis of the day's closing share prices or the closing share prices on the last day of a week and a month (excluding dividend yields) according to the following formula:

$$
R_{i t}=\left(\ln P_{t}-\ln P_{i, t-1}\right) \times 100
$$

where:

$R_{i t}$ - daily, weekly, monthly rate of return on the $i$-th share in the period $t$,

$P_{i t}-$ price of the $i$-th share in the period $t$,

$P_{i, t-1}$ - price of the $i$-th share in the period $t-1$.

To estimate beta parameters we used a single-index model by Sharpe ${ }^{33}$ in the form:

$$
R_{i t}=\alpha_{i}+\beta_{i} R_{W I G t}+\varepsilon_{i t}
$$


where:

$R_{i t}-$ rate of return of the $i$-th share in the period $t$,

$\alpha_{i}$ - alfa parameter (intercept),

$\beta_{i}$ - beta parameter (slope),

$R_{W I G t}$ - rate of return of WIG index in the period $t$,

$\varepsilon_{i t}-$ random term, $E\left(\varepsilon_{i t}\right)=0$.

A single-index model was used for the estimation of the beta parameter measuring the investment risk of shares on the basis of daily, weekly and monthly rates of return. The parameters of the model were estimated by the ordinary least squares (OLS) method (with the use of the calculation platform Matlab).

An index representing the market portfolio was assumed to be WIG. The performance of WIG index in the examined period 2005-2012 is presented in Figure 1.

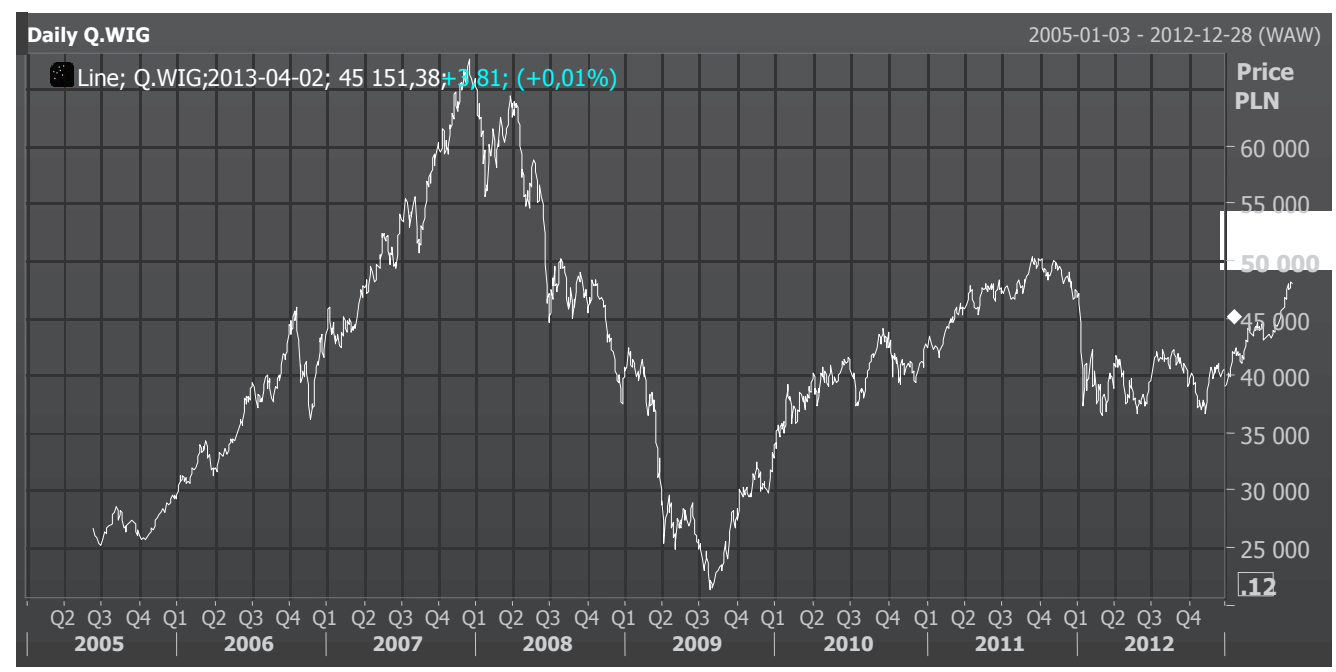

Fig. 1. WIG Index in the period of 2005-2012 (daily data)

Source: authors' own calculations in Thomson Reuters. 


\section{Analysis of the obtained findings (results)}

The estimation results of the beta parameter for companies from WIG20 index in all the rate of return measurement intervals are presented below in the Tables 1-3, while those for companies from mWIG40 index in the Tables 4-6.

Legend for the assumed symbols in the tables: subscript $D, W, M$ standing at the estimate of $\alpha$ and $\beta$ parameters indicates its estimate respectively for the daily (D), weekly (W) and monthly data (M), $R^{2}$ - determination coefficient, $D W$ - estimate of Durbin-Watson statistics, $p$-value under the estimates of $\alpha$ and $\beta$ parameters indicates the significance level for $t$-Student test.

Table 1. Estimation results for companies from WIG20 index, daily data

\begin{tabular}{|c|c|c|c|c|}
\hline Company & $\begin{array}{c}\alpha_{D} \\
p \text {-value }\end{array}$ & $\begin{array}{c}\beta_{D} \\
p \text {-value }\end{array}$ & $R^{2}$ & $D W$ \\
\hline ASSECO & $\begin{array}{l}0.003 \\
0.937\end{array}$ & $\begin{array}{l}0.733 \\
0.000\end{array}$ & 0.239 & 2.043 \\
\hline BRE & $\begin{array}{l}0.022 \\
0.575\end{array}$ & $\begin{array}{l}1.257 \\
0.000\end{array}$ & 0.489 & 2.015 \\
\hline GTC & $\begin{array}{r}-0.003 \\
0.965\end{array}$ & $\begin{array}{l}0.130 \\
0.004\end{array}$ & 0.004 & 2.040 \\
\hline KGHM & $\begin{array}{l}0.046 \\
0.330\end{array}$ & $\begin{array}{l}1.512 \\
0.000\end{array}$ & 0.498 & 1.794 \\
\hline PKN ORLEN & $\begin{array}{r}-0.021 \\
0.539\end{array}$ & $\begin{array}{l}1.211 \\
0.000\end{array}$ & 0.538 & 2.003 \\
\hline TPSA & $\begin{array}{r}-0.044 \\
0.223\end{array}$ & $\begin{array}{l}0.704 \\
0.000\end{array}$ & 0.265 & 2.126 \\
\hline BANK HANDLOWY & $\begin{array}{l}0.000 \\
0.993\end{array}$ & $\begin{array}{l}0.729 \\
0.000\end{array}$ & 0.246 & 2.019 \\
\hline LOTOS & $\begin{array}{r}-0.013 \\
0.751 \\
\end{array}$ & $\begin{array}{l}1.042 \\
0.000\end{array}$ & 0.399 & 1.680 \\
\hline PEKAO & $\begin{array}{r}-0.031 \\
0.367 \\
\end{array}$ & $\begin{array}{l}1.396 \\
0.000\end{array}$ & 0.621 & 2.072 \\
\hline PGNIG & $\begin{array}{l}0.008 \\
0.839\end{array}$ & $\begin{array}{l}0.655 \\
0.000\end{array}$ & 0.250 & 1.973 \\
\hline PKO & $\begin{array}{r}-0.018 \\
0.531\end{array}$ & $\begin{array}{l}1.267 \\
0.000\end{array}$ & 0.643 & 2.037 \\
\hline TNV & $\begin{array}{r}-0.016 \\
0.733\end{array}$ & $\begin{array}{l}0.961 \\
0.000\end{array}$ & 0.290 & 1.828 \\
\hline BORYSZEW & $\begin{array}{r}-0.021 \\
0.724\end{array}$ & $\begin{array}{l}0.615 \\
0.000\end{array}$ & 0.095 & 1.633 \\
\hline SYNTHOS & $\begin{array}{l}0.086 \\
0.076\end{array}$ & $\begin{array}{l}0.742 \\
0.000\end{array}$ & 0.185 & 1.756 \\
\hline
\end{tabular}

Source: own calculations. 
Table 2. Estimation results for companies from WIG20 index, weekly data

\begin{tabular}{|c|c|c|c|c|c|}
\hline Company & $\begin{array}{c}\alpha_{W} \\
p \text {-value }\end{array}$ & $\begin{array}{c}\beta_{W} \\
p \text {-value }\end{array}$ & $R^{2}$ & $D W$ & $\begin{array}{c}p \text {-value } \mathrm{H} 0: \\
\beta_{W}=\beta_{D} \text { (const) }\end{array}$ \\
\hline ASSECO & $\begin{array}{l}0.015 \\
0.939\end{array}$ & $\begin{array}{l}0.735 \\
0.000\end{array}$ & 0.248 & 2.115 & 0.967 \\
\hline BRE & $\begin{array}{l}0.085 \\
0.647\end{array}$ & $\begin{array}{l}1.394 \\
0.000\end{array}$ & 0.565 & 2.000 & 0.023 \\
\hline GTC & $\begin{array}{r}-0.179 \\
0.462\end{array}$ & $\begin{array}{l}1.209 \\
0.000\end{array}$ & 0.362 & 2.238 & 0.000 \\
\hline KGHM & $\begin{array}{l}0.209 \\
0.383\end{array}$ & $\begin{array}{l}1.617 \\
0.000\end{array}$ & 0.512 & 2.114 & 0.175 \\
\hline PKN ORLEN & $\begin{array}{r}-0.088 \\
0.599 \\
\end{array}$ & $\begin{array}{l}1.147 \\
0.000\end{array}$ & 0.520 & 2.302 & 0.240 \\
\hline TPSA & $\begin{array}{r}-0.201 \\
0.215\end{array}$ & $\begin{array}{l}0.648 \\
0.000\end{array}$ & 0.269 & 2.088 & 0.294 \\
\hline BANK HANDLOWY & $\begin{array}{r}-0.022 \\
0.906\end{array}$ & $\begin{array}{l}0.903 \\
0.000\end{array}$ & 0.354 & 2.010 & 0.000 \\
\hline LOTOS & $\begin{array}{r}-0.064 \\
0.779\end{array}$ & $\begin{array}{l}1.039 \\
0.000\end{array}$ & 0.341 & 2.001 & 0.974 \\
\hline PEKAO & $\begin{array}{r}-0.129 \\
0.352 \\
\end{array}$ & $\begin{array}{l}1.255 \\
0.000\end{array}$ & 0.653 & 2.115 & 0.002 \\
\hline PGNIG & $\begin{array}{l}0.056 \\
0.749\end{array}$ & $\begin{array}{l}0.539 \\
0.000\end{array}$ & 0.207 & 2.070 & 0.034 \\
\hline $\mathrm{PKO}$ & $\begin{array}{r}-0.084 \\
0.520\end{array}$ & $\begin{array}{l}1.211 \\
0.000\end{array}$ & 0.663 & 1.998 & 0.182 \\
\hline TVN & $\begin{array}{r}-0.097 \\
0.680 \\
\end{array}$ & $\begin{array}{l}1.095 \\
0.000\end{array}$ & 0.335 & 2.105 & 0.000 \\
\hline BORYSZEW & $\begin{array}{r}-0.152 \\
0.627\end{array}$ & $\begin{array}{l}0.861 \\
0.000\end{array}$ & 0.150 & 1.583 & 0.000 \\
\hline SYNTHOS & $\begin{array}{l}0.404 \\
0.098\end{array}$ & $\begin{array}{l}0.878 \\
0.000\end{array}$ & 0.231 & 1.895 & 0.083 \\
\hline
\end{tabular}

Source: own calculations.

The values of estimates of the beta parameter for companies from WIG20 index, for all the daily, weekly and monthly data (Table 1-3), indicate that all the estimates are statistically significant, that is they indicate (on the level 0.01) the rejection of the zero hypothesis stating that the beta parameter equals zero. In all the cases the statistically high significance of the estimate of this parameter was achieved. Additionally what was verified was the hypothesis claiming the equality of the beta parameter estimated on the weekly data with the parameter obtained on the daily data (the significance level of the test in the last column of Table 2), as well as the equality of the beta parameter on the monthly data with the parameter on the weekly data (the significance level of the test in the last column of Table 3). The zero hypothesis was verified here, namely that $\beta_{W}=\beta_{D}$ (where $\beta_{D}$ is constant) and that $\beta_{M}=\beta_{W}$ (where $\beta_{W}$ is constant). The verification is conducted on the basis of statistics which has the t-Student distribution with 
$n-2$ degrees of freedom ${ }^{34}$. The presented p-values in the last column in Table 2 indicate that for 7 companies at the significance level of at least 0.05 (for 8 at the level of 0.1 ) the above formulated zero hypothesis should be rejected, namely that those parameters are different from the statistical viewpoint. On the other hand, for 7 companies there are no reasons to reject such a hypothesis. However, the p-values in the last column of table 3 indicate that for 2 companies at the significance level of 0.05 (for 5 at the level of 0.1 ) the zero hypothesis about the equality of the beta parameter for the monthly data with those to the weekly data should be rejected, while in the case of 12 companies there are no reasons to reject such a hypothesis.

Table 3. Estimation results for companies from WIG20 index, monthly data

\begin{tabular}{|c|c|c|c|c|c|}
\hline Company & $\begin{array}{c}\alpha_{M} \\
p \text {-value }\end{array}$ & $\begin{array}{c}\beta_{M} \\
p \text {-value }\end{array}$ & $R^{2}$ & $D W$ & $\begin{array}{c}p \text {-value } \mathrm{H}_{0}: \\
\beta_{M}=\beta_{W} \text { (const) }\end{array}$ \\
\hline ASSECO & $\begin{array}{l}0.030 \\
0.965\end{array}$ & $\begin{array}{l}0.795 \\
0.000\end{array}$ & 0.407 & 2.217 & 0.546 \\
\hline BRE & $\begin{array}{l}0.275 \\
0.707\end{array}$ & $\begin{array}{l}1.577 \\
0.000\end{array}$ & 0.699 & 2.301 & 0.090 \\
\hline GTC & $\begin{array}{r}-0.652 \\
0.466\end{array}$ & $\begin{array}{l}1.116 \\
0.000\end{array}$ & 0.440 & 1.832 & 0.477 \\
\hline KGHM & $\begin{array}{l}1.037 \\
0.295\end{array}$ & $\begin{array}{l}1.398 \\
0.000\end{array}$ & 0.502 & 1.692 & 0.132 \\
\hline PKN ORLEN & $\begin{array}{r}-0.317 \\
0.592\end{array}$ & $\begin{array}{l}0.993 \\
0.000\end{array}$ & 0.588 & 1.977 & 0.076 \\
\hline TPSA & $\begin{array}{r}-0.747 \\
0.273\end{array}$ & $\begin{array}{l}0.408 \\
0.000\end{array}$ & 0.153 & 2.116 & 0.017 \\
\hline BANK HANDLOWY & $\begin{array}{r}-0.131 \\
0.866 \\
\end{array}$ & $\begin{array}{l}0.958 \\
0.000\end{array}$ & 0.435 & 2.529 & 0.628 \\
\hline LOTOS & $\begin{array}{r}-0.307 \\
0.791 \\
\end{array}$ & $\begin{array}{l}1.177 \\
0.000\end{array}$ & 0.362 & 2.137 & 0.410 \\
\hline PEKAO & $\begin{array}{r}-0.530 \\
0.326 \\
\end{array}$ & $\begin{array}{l}1.216 \\
0.000\end{array}$ & 0.720 & 2.404 & 0.619 \\
\hline PGNIG & $\begin{array}{l}0.214 \\
0.767\end{array}$ & $\begin{array}{l}0.466 \\
0.000\end{array}$ & 0.196 & 1.969 & 0.478 \\
\hline PKO & $\begin{array}{r}-0.350 \\
0.506\end{array}$ & $\begin{array}{l}1.212 \\
0.000\end{array}$ & 0.727 & 1.689 & 0.991 \\
\hline TVN & $\begin{array}{r}-0.275 \\
0.745\end{array}$ & $\begin{array}{l}0.864 \\
0.000\end{array}$ & 0.346 & 1.899 & 0.063 \\
\hline BORYSZEW & $\begin{array}{r}-0.904 \\
0.569 \\
\end{array}$ & $\begin{array}{l}1.456 \\
0.000\end{array}$ & 0.318 & 1.613 & 0.010 \\
\hline SYNTHOS & $\begin{array}{l}1.682 \\
0.161 \\
\end{array}$ & $\begin{array}{l}0.982 \\
0.000\end{array}$ & 0.254 & 1.612 & 0.551 \\
\hline
\end{tabular}

Source: own calculations.

It must also be stated that the obtained estimates of the intercept ( $\alpha$ parameter) are not significant (besides for the SYNTHOS company for the daily and weekly data) from the statistical viewpoint. The obtained values of the determination coefficient indicate that when 
estimating a simple Sharpe's model for the companies from the Polish stock market, the highest levels of explanation were achieved for the monthly data, lower for the weekly data and the lowest ones for the daily data, which is a result of the respectively rising (together with the growing measurement frequency) changeability of the rates of return, on the basis of which the model was estimated. That conclusion is coincident with the statement by K.Smith ${ }^{35}$. The estimates of statistics of the Durbin-Watson test indicate that in the estimated models there is no autocorrelation of random term.

Table 4. Estimation results for companies from mWIG40 index, daily data

\begin{tabular}{|c|c|c|c|c|}
\hline Company & $\begin{array}{c}\alpha_{D} \\
p \text {-value }\end{array}$ & $\begin{array}{c}\beta_{D} \\
p \text {-value }\end{array}$ & $R^{2}$ & $D W$ \\
\hline AGORA & $\begin{array}{r}-0.109 \\
0.030\end{array}$ & $\begin{array}{l}0.776 \\
0.000\end{array}$ & 0.187 & 1.949 \\
\hline MILLENIUM & $\begin{array}{r}-0.012 \\
0.818 \\
\end{array}$ & $\begin{array}{l}1.102 \\
0.000\end{array}$ & 0.316 & 1.911 \\
\hline BUDIMEX & $\begin{array}{l}0.009 \\
0.854 \\
\end{array}$ & $\begin{array}{l}0.561 \\
0.000\end{array}$ & 0.109 & 1.856 \\
\hline BIOTON & $\begin{array}{r}-0.083 \\
0.292\end{array}$ & $\begin{array}{l}0.751 \\
0.000\end{array}$ & 0.085 & 1.938 \\
\hline CIECH & $\begin{array}{r}-0.024 \\
0.632 \\
\end{array}$ & $\begin{array}{l}0.714 \\
0.000\end{array}$ & 0.167 & 1.631 \\
\hline EMPERIA & $\begin{array}{l}0.057 \\
0.274\end{array}$ & $\begin{array}{l}0.006 \\
0.863 \\
\end{array}$ & 0.000 & 1.716 \\
\hline ECHO & $\begin{array}{l}0.046 \\
0.414\end{array}$ & $\begin{array}{r}-0.023 \\
0.566\end{array}$ & 0.000 & 1.839 \\
\hline IMPEXMET & $\begin{array}{l}0.000 \\
0.997\end{array}$ & $\begin{array}{l}0.934 \\
0.000\end{array}$ & 0.203 & 1.795 \\
\hline KETY & $\begin{array}{l}0.001 \\
0.980\end{array}$ & $\begin{array}{l}0.149 \\
0.000\end{array}$ & 0.011 & 1.999 \\
\hline ORBIS & $\begin{array}{l}0.007 \\
0.887\end{array}$ & $\begin{array}{l}0.502 \\
0.000\end{array}$ & 0.095 & 2.118 \\
\hline ROVESE & $\begin{array}{r}-0.116 \\
0.082\end{array}$ & $\begin{array}{l}0.961 \\
0.000\end{array}$ & 0.168 & 1.749 \\
\hline AMREST & $\begin{array}{l}0.054 \\
0.252\end{array}$ & $\begin{array}{l}0.570 \\
0.000\end{array}$ & 0.130 & 1.871 \\
\hline EUROCASH & $\begin{array}{l}0.129 \\
0.011\end{array}$ & $\begin{array}{l}0.067 \\
0.062\end{array}$ & 0.002 & 2.013 \\
\hline IDMSA & $\begin{array}{r}-0.089 \\
0.254\end{array}$ & $\begin{array}{l}1.109 \\
0.000\end{array}$ & 0.184 & 1.682 \\
\hline KOPEX & $\begin{array}{l}0.064 \\
0.326 \\
\end{array}$ & $\begin{array}{l}0.244 \\
0.000\end{array}$ & 0.013 & 1.803 \\
\hline POLIMEX & $\begin{array}{r}-0.066 \\
0.256 \\
\end{array}$ & $\begin{array}{l}0.981 \\
0.000\end{array}$ & 0.214 & 1.883 \\
\hline NETIA & $\begin{array}{r}-0.005 \\
0.896\end{array}$ & $\begin{array}{l}0.100 \\
0.000\end{array}$ & 0.007 & 1.960 \\
\hline PUŁAWY & $\begin{array}{l}0.040 \\
0.390\end{array}$ & $\begin{array}{l}0.616 \\
0.000\end{array}$ & 0.171 & 1.760 \\
\hline ING BANK & $\begin{array}{l}0.022 \\
0.549\end{array}$ & $\begin{array}{l}0.694 \\
0.000\end{array}$ & 0.250 & 1.955 \\
\hline
\end{tabular}

Source: own calculations. 
Table 5. Estimation results for companies from mWIG40 index, weekly data

\begin{tabular}{|c|c|c|c|c|c|}
\hline Company & $\begin{array}{c}\alpha_{W} \\
p \text {-value }\end{array}$ & $\begin{array}{c}\beta_{W} \\
p \text {-value }\end{array}$ & $R^{2}$ & $D W$ & $\begin{array}{c}p \text {-value } \mathrm{H}_{0}: \\
\beta_{W}=\beta_{D} \text { (const) }\end{array}$ \\
\hline AGORA & $\begin{array}{r}-0.538 \\
0.030\end{array}$ & $\begin{array}{l}0.928 \\
0.000\end{array}$ & 0.244 & 2.145 & 0.058 \\
\hline MILLENIUM & $\begin{array}{r}-0.088 \\
0.716\end{array}$ & $\begin{array}{l}1.360 \\
0.000\end{array}$ & 0.423 & 2.264 & 0.001 \\
\hline BUDIMEX & $\begin{array}{l}0.027 \\
0.914\end{array}$ & $\begin{array}{l}0.694 \\
0.000\end{array}$ & 0.146 & 2.176 & 0.107 \\
\hline BIOTON & $\begin{array}{r}-0.413 \\
0.201 \\
\end{array}$ & $\begin{array}{l}0.720 \\
0.000\end{array}$ & 0.108 & 1.897 & 0.765 \\
\hline $\mathrm{CIECH}$ & $\begin{array}{r}-0.130 \\
0.635\end{array}$ & $\begin{array}{l}0.972 \\
0.000\end{array}$ & 0.228 & 1.944 & 0.004 \\
\hline EMPERIA & $\begin{array}{l}0.192 \\
0.423\end{array}$ & $\begin{array}{l}0.472 \\
0.000\end{array}$ & 0.082 & 1.846 & 0.000 \\
\hline $\mathrm{ECHO}$ & $\begin{array}{l}0.051 \\
0.824\end{array}$ & $\begin{array}{l}1.185 \\
0.000\end{array}$ & 0.380 & 2.045 & 0.000 \\
\hline IMPEX MET & $\begin{array}{r}-0.049 \\
0.865 \\
\end{array}$ & $\begin{array}{l}1.127 \\
0.000\end{array}$ & 0.256 & 2.072 & 0.000 \\
\hline KETY & $\begin{array}{r}-0.069 \\
0.729\end{array}$ & $\begin{array}{l}0.628 \\
0.000\end{array}$ & 0.189 & 2.096 & 0.000 \\
\hline ORBIS & $\begin{array}{r}-0.024 \\
0.912\end{array}$ & $\begin{array}{l}0.849 \\
0.000\end{array}$ & 0.253 & 2.105 & 0.000 \\
\hline ROVESE & $\begin{array}{r}-0.577 \\
0.076 \\
\end{array}$ & $\begin{array}{l}1.040 \\
0.000\end{array}$ & 0.191 & 2.110 & 0.458 \\
\hline AMREST & $\begin{array}{l}0.217 \\
0.329\end{array}$ & $\begin{array}{l}0.842 \\
0.000\end{array}$ & 0.259 & 2.187 & 0.000 \\
\hline EUROCASH & $\begin{array}{l}0.562 \\
0.009\end{array}$ & $\begin{array}{l}0.595 \\
0.000\end{array}$ & 0.151 & 2.179 & 0.000 \\
\hline IDMSA & $\begin{array}{r}-0.425 \\
0.307\end{array}$ & $\begin{array}{l}1.039 \\
0.000\end{array}$ & 0.142 & 1.437 & 0.598 \\
\hline KOPEX & $\begin{array}{l}0.183 \\
0.544\end{array}$ & $\begin{array}{l}1.102 \\
0.000\end{array}$ & 0.237 & 2.055 & 0.000 \\
\hline POLIMEX & $\begin{array}{r}-0.332 \\
0.250 \\
\end{array}$ & $\begin{array}{l}1.017 \\
0.000\end{array}$ & 0.223 & 1.997 & 0.700 \\
\hline NETIA & $\begin{array}{r}-0.051 \\
0.773 \\
\end{array}$ & $\begin{array}{l}0.451 \\
0.000\end{array}$ & 0.129 & 2.100 & 0.000 \\
\hline PUŁAWY & $\begin{array}{l}0.166 \\
0.488 \\
\end{array}$ & $\begin{array}{l}0.868 \\
0.000\end{array}$ & 0.266 & 1.815 & 0.001 \\
\hline ING BANK & $\begin{array}{l}0.076 \\
0.645\end{array}$ & $\begin{array}{l}0.858 \\
0.000\end{array}$ & 0.385 & 1.862 & 0.002 \\
\hline
\end{tabular}

Source: own calculations. 
Table 6. Estimation results for companies from mWIG40 index, monthly data

\begin{tabular}{|c|c|c|c|c|c|}
\hline Company & $\begin{array}{c}\alpha_{M} \\
p \text {-value }\end{array}$ & $\begin{array}{c}\beta_{M} \\
p \text {-value }\end{array}$ & $R^{2}$ & $D W$ & $\begin{array}{c}p \text {-value } \mathrm{H}_{0}: \\
\beta_{M}=\beta_{W} \text { (const) }\end{array}$ \\
\hline AGORA & $\begin{array}{r}-2.484 \\
0.013\end{array}$ & $\begin{array}{l}1.034 \\
0.000\end{array}$ & 0.364 & 1.590 & 0.458 \\
\hline MILLENIUM & $\begin{array}{r}-0.628 \\
0.443\end{array}$ & $\begin{array}{l}1.743 \\
0.000\end{array}$ & 0.696 & 2.043 & 0.002 \\
\hline BUDIMEX & $\begin{array}{l}0.145 \\
0.891\end{array}$ & $\begin{array}{l}0.639 \\
0.000\end{array}$ & 0.155 & 2.036 & 0.724 \\
\hline BIOTON & $\begin{array}{r}-1.771 \\
0.300\end{array}$ & $\begin{array}{l}0.818 \\
0.001\end{array}$ & 0.108 & 1.966 & 0.692 \\
\hline $\mathrm{CIECH}$ & $\begin{array}{r}-0.889 \\
0.461\end{array}$ & $\begin{array}{l}1.313 \\
0.000\end{array}$ & 0.381 & 1.970 & 0.054 \\
\hline EMPERIA & $\begin{array}{l}0.748 \\
0.527\end{array}$ & $\begin{array}{l}0.660 \\
0.000\end{array}$ & 0.136 & 2.327 & 0.277 \\
\hline ECHO & $\begin{array}{l}0.137 \\
0.881\end{array}$ & $\begin{array}{l}1.341 \\
0.000\end{array}$ & 0.521 & 2.057 & 0.242 \\
\hline IMPEXMET & $\begin{array}{r}-0.279 \\
0.811\end{array}$ & $\begin{array}{l}1.406 \\
0.000\end{array}$ & 0.424 & 2.057 & 0.000 \\
\hline KETY & $\begin{array}{r}-0.407 \\
0.624 \\
\end{array}$ & $\begin{array}{l}0.850 \\
0.000\end{array}$ & 0.347 & 2.495 & 0.068 \\
\hline ORBIS & $\begin{array}{r}-0.154 \\
0.849 \\
\end{array}$ & $\begin{array}{l}0.994 \\
0.000\end{array}$ & 0.431 & 1.894 & 0.219 \\
\hline ROVESE & $\begin{array}{r}-2.465 \\
0.076 \\
\end{array}$ & $\begin{array}{l}1.042 \\
0.000\end{array}$ & 0.224 & 1.834 & 0.988 \\
\hline AMREST & $\begin{array}{l}0.867 \\
0.350\end{array}$ & $\begin{array}{l}0.964 \\
0.000\end{array}$ & 0.366 & 2.416 & 0.364 \\
\hline EUROCASH & $\begin{array}{l}2.441 \\
0.005\end{array}$ & $\begin{array}{l}0.583 \\
0.000\end{array}$ & 0.197 & 2.426 & 0.921 \\
\hline IDMSA & $\begin{array}{r}-2.083 \\
0.390\end{array}$ & $\begin{array}{l}1.661 \\
0.000\end{array}$ & 0.212 & 1.640 & 0.075 \\
\hline KOPEX & $\begin{array}{l}0.805 \\
0.530\end{array}$ & $\begin{array}{l}1.550 \\
0.000\end{array}$ & 0.433 & 1.869 & 0.017 \\
\hline POLIMEX & $\begin{array}{r}-1.521 \\
0.263\end{array}$ & $\begin{array}{l}1.193 \\
0.000\end{array}$ & 0.281 & 2.267 & 0.374 \\
\hline NETIA & $\begin{array}{r}-0.332 \\
0.674\end{array}$ & $\begin{array}{l}0.480 \\
0.000\end{array}$ & 0.157 & 2.028 & 0.802 \\
\hline PUŁAWY & $\begin{array}{l}0.668 \\
0.548 \\
\end{array}$ & $\begin{array}{l}0.957 \\
0.000\end{array}$ & 0.306 & 1.730 & 0.577 \\
\hline ING BANK & $\begin{array}{l}0.215 \\
0.776\end{array}$ & $\begin{array}{l}1.113 \\
0.000\end{array}$ & 0.520 & 1.736 & 0.023 \\
\hline
\end{tabular}

Source: own calculations.

The results of the estimation and verification of the aforementioned hypotheses for 19 companies from mWIG40 index are presented above in the Tables 4-6. They are to a large extent similar to the results obtained in the case of the companies from WIG20 index. It results from those findings that all the estimates of the beta parameter for the companies from mWIG40 index obtained for the daily, weekly and monthly data (apart from two cases) (for the significance 
level 0.01) are indeed different from zero from a statistical point of view, however the estimates of the $\alpha$ parameter (apart from 9 cases) are statistically not significant. On the basis of the obtained $p$-values - the last column of table 5 - one can state that at the significance level of 0.05 for 14 companies (at the level of 0.1 for 15 ones) one should reject the zero hypothesis about the equality of the beta parameter estimates for the weekly and daily data, while in the case of 5 companies there are no reasons to reject such a hypothesis. However, the $p$-values from the last column of table 6 indicate that at the significance level of 0.05 for 4 companies (on the level of 0.1 for 7 companies) one should reject the zero hypothesis about the equality of the beta parameter estimates for the monthly and weekly data, and for 15 companies there are no reasons to reject such a hypothesis. Moreover, a formerly formulated conclusion has been confirmed that the values of determination coefficients are higher in the model estimated on the monthly data, lower for the weekly data and the lowest for the daily data. The estimates of the statistics of the Durbin-Watson test indicate that in the estimated model for all companies we do not have to do with the autocorrelation of a random term.

\section{Conclusions}

The presented research embraced the significance of estimates of the beta parameter with respect to the measurement frequency of the rate of return from shares for 33 largest companies from the Warsaw Stock Exchange. Essential differences were found in the absolute values of the obtained estimates for the daily, weekly and monthly data, however there was no explicit answer to the question whether the estimates of those parameters differ from the statistical point of view. It has been claimed, however, that (at the significance level of 0.05$)$ for $21(63.6 \%)$ companies the estimates of beta parameters for the weekly and daily data while in the case of $6(18.2 \%)$ companies the estimates obtained for the monthly and weekly data are not equal statistically. For the significance level 0.1 these numbers are respectively 23 (69.7\%) and 12 (36.4\%). Therefore a conclusion can be drawn that there is a bigger convergence between the estimates of the beta parameter on the weekly and daily data than on the monthly and weekly ones. It has a also been observed that the values of the determination coefficients are increasing as long as the rate of return measurement frequency is decreasing, which in fact results from the decrease of the amplitude of fluctuations of the observed rate of return values. In the estimated model there is also no autocorrelation of the random term.

It could be also noted that the beta changes with the return interval. The absolute value of the beta generally increases with the decreasing rate of return measurement frequency. For 
companies belonging to WIG20 index beta values have grown in 7 cases, while for mWIG40 index - in 16 cases.

\section{Notes}

${ }_{1}^{1}$ The data comes from the Thomson Reuters service and it is the longest possible complete sample that was successfully collected.

${ }^{2}$ Maddala (2008), pp. 116-117.

${ }^{3}$ Sharpe (1963), pp. 277-293.

${ }^{4}$ Blume (1971), pp. 1-10.

${ }^{5}$ Levy (1971), pp. 55-62.

${ }^{6}$ Levy (1974), pp. 61-69.

${ }^{7}$ Fabozzi, Francis (1977), pp. 1093-1099.

${ }^{8}$ Kim, Zumwalt (1979), pp. 1015-1025.

${ }^{9}$ Eubank, Zumwalt (1979), pp. 1015-1025.

${ }^{10}$ Chen (1982), pp. 265-286.

${ }_{11}$ Alexander, Benson (1982), pp. 27-36.

${ }^{12}$ Fisher, Kamin (1985), pp. 127-149.

13 Brennan, Copeland (1988), pp. 1009-1013.

${ }^{14}$ Lin, Chen (1990), pp. 19-37.

15 Clarkson, Thompson (1990), pp. 431-453.

${ }^{16}$ Sercu et al. (2008), pp. 1196-1219.

${ }^{17}$ Hawawini (1983), pp. 73-77.

${ }^{18}$ Handa et al. (1989), pp. 79-100.

19 Daves et al. (2000), p. 7-13.

${ }^{20}$ Damodaran (2001).

${ }^{21}$ Saniga et al. (1981), p. 129-135.

22 Corhay (1992), pp. 61-73.

${ }^{23}$ Mukherji (2009), pp. 117-122.

${ }^{24}$ Krishna (2010), pp. 162-167.

25 Armitage, Brzeszczynski (2011), pp. 1525-1538.

${ }^{26}$ Feder-Sempach (2011), pp. 141-145.

27 Brzeszczyński et al. (2011), pp. 28-49.

28 Smith (1978), pp. 313-332.

${ }^{29}$ Cohen (1980), pp. 249-257.

${ }^{30}$ Bjornson (1999), pp. 77-100.

${ }^{31}$ Handa et al. (1993), pp. 15-43.

32 Daves (2000), pp. 7-13.

33 Sharpe (1964), pp. 425-442.

34 Maddala (2008).

35 Smith (1978). 


\section{References}

Alexander, G.J. \& Benson, P.G. (1982). More on Beta as a Random Coefficient. Journal of Financial and Quantitative Analysis, 17, 1.

Armitage, S. \& Brzeszczynski, J. (2011). Heteroscedasticity and interval effects in estimating beta: UK evidence. Applied Financial Economics, 21, 20.

Bjornson, B., Kim, H. \& Lee, K. (1999). Low and high frequency macroeconomic forces in asset pricing. Quarterly Review of Economics and Finance, 39.

Blume, M.E. (1971). On the Assessment of Risk. Journal of Finance, 26, 1.

Brennan, M.J. \& Copeland, T.E. (1988). Beta Changes around Stock Splits: A Note. Journal of Finance, 43, 4.

Brzeszczyński, J., Gajdka, J. \& Schabek, T. (2011). The Role of Stock Size and Trading Intensity in the Magnitude of the „Interval Effect” in Beta Estimation: Empirical Evidence from the Polish Capital Market. Emerging Markets Finance \& Trade, 47, 1.

Chen, S. (1982). An Examination of Risk-Return Relationship in Bull and Bear Markets Using Time-Varying Betas. Journal of Financial and Quantitative Analysis, 17, 2.

Clarkson, P.M. \& Thompson, R. (1990). Empirical Estimates of Beta When Investors Face Estimation Risk. Journal of Finance, 45, 2.

Cohen, K., Hawawini, G., Maier, S., Schwartz, R. \& Whitcomb, D. (1980). Implications of microstructure theory for empirical research in stock price behavior. Journal of Finance, 35 .

Corhay, A. (1992). The intervalling effect bias in beta: A note. Journal of Banking \& Finance, $16,1$.

Damodaran, A. (2001). The Dark Side of Valuation. New York: Prentice Hall.

Daves, P.R., Ehrhardt, M.C. \& Kunkel, R.A. (2000). Estimating systematic risk: The choice of return interval and estimation period. Journal of Financial and Strategic Decisions, 13, 1.

Eubank, A.A. \& Zumwalt, J.K. (1979). An Analysis of the Forecast Error Impact of Alternative Beta Adjustment Techniques and Risk Classes. The Journal of Finance, 34, 3.

Fabozzi, F.F. \& Francis, J.C. (1977). Stability Tests for Alphas and Betas over Bull and Bear Market Conditions. The Journal of Finance, 32, 2.

Feder-Sempach, E. (2011). Ryzyko inwestycyjne. Analiza polskiego rynku akcji. Warszawa: CeDeWu.

Fisher, L. \& Kamin, J.H. (1985). Forecasting Systematic Risk: Estimates of "Raw" Beta that Take Account of the Tendency of Beta to Change and the Heteroskedasticity of Residual Returns. Journal of Financial and Quantitative Analysis, 20, 2.

Handa, P., Kothari, S.P. \& Wasley, C. (1989). The relation between the return interval and betas: Implications for the size effect. Journal of Financial Economics, 23. 
Handa, P., Kothari, S. \& Wasley, C. (1993). Sensitivity of Multivariate Tests of the CAPM to the. Return Measurement Interval. Journal of Finance, 48.

Hawawini, G. (1983). Why Beta Shifts as the Return Interval Changes. Financial Analysts Journal, 39.

Kim, M. \& Zumwalt, K. (1979). An Analysis of Risk in Bull and Bear Markets. Journal of Financial and Quantitative Analysis, 14. 5.

Krishna, Y.R. (2010). Estimating Systematic Risk: The Return Interval and Proxy for the Market Effect. International Research Journal of Finance and Economics, 51.

Levy, R.A. (1971). On the Short Term Stationarity of Beta Coefficient. Financial Analysts Journal, $27,6$.

Levy, R.A. (1974). Beta Coefficient as Predictors of Return. Financial Analysts Journal, 30, 1.

Lin, W.T. \& Chen, Y.H. (1990). Investment Horizon and Beta Coefficient. Journal of Business Research, 21, 1 .

Maddala, G.S. (2008). Ekonometria. Warszawa: Wydawnictwo Naukowe PWN.

Mukherji, S. (2009). The Impact of the Return Interval on Beta Estimation. Journal of International Finance and Economics, 9, 1.

Saniga, E.M., McInish, T.H. \& Gouldey, B.K. (1981). The Effect of Differencing Interval Length on Beta. The Journal of Financial Research, 4, 2.

Sercu, P., Vanderbroek, M. \& Vinaimont, T. (2008). Thin - Trading Effects in Beta: Bias v. Estimation Error. Journal of Business Finance and Accounting, 35, 9/10.

Sharpe, W.F. (1963). A Simplified Model of Portfolio Analysis. Management Science, 9, 2.

Sharpe, W.F. (1964). Capital asset prices: A theory of market equilibrium under condition of risk. Journal of Finance, 19.

Smith, K. (1978). The Effect of Intervaling on estimating Parameters of the Capital Asset pricing Model. Journal of Financial and Quantitative Analysis, 23. 